\title{
Analgesic, Anti-Inflammatory and Anti-Biofilm- Forming Activity of Potato (Solanum tuberosum L.) Peel Extract
}

\author{
Ivan Arie Wahyudi ${ }^{1}$, Fahri Reza Ramadhan ${ }^{2}$, Rama Insan Kusuma Wijaya ${ }^{2}$, Retno Ardhani ${ }^{1}$, \\ Trianna Wahyu Utami ${ }^{1}$
}

\author{
${ }^{1}$ Department of Dental Biomedical Sciences, Faculty of Dentistry, Universitas Gadjah Mada, Indonesia \\ ${ }^{2}$ Faculty of Dentistry, Universitas Gadjah Mada, Indonesia
}

\begin{abstract}
The utilization of natural resources, one of which is plants, has been researched as an alternative to synthetic drugs because of their natural content. Potato (Solanum tuberosum L.) peels, the parts of potatoes that are often cut off and discarded, have been reported to have some phenolic compounds and flavonoids in their composition. The extract of potato peels was investigated for its analgesic, anti-inflammatory, and anti-biofilm-forming properties. A hot plate test was conducted to assess the analgesic activity in treatment doses of $50 \mathrm{mg} / \mathrm{kg}, 100 \mathrm{mg} / \mathrm{kg}$, and $200 \mathrm{mg} / \mathrm{kg}$ with paracetamol as the reference drug and distilled water as the negative control, while carrageenan-induced paw edema was used to assess anti-inflammatory activity in treatment doses of $100 \mathrm{mg} / \mathrm{kg}, 200 \mathrm{mg} / \mathrm{kg}$, and $400 \mathrm{mg} /$ $\mathrm{kg}$ with diclofenac as the reference drug and distilled water as the negative control. Antibiofilm-forming activity was tested by using the crystal violet assay. The results showed that, compared with the negative control, treatment doses of $100 \mathrm{mg} / \mathrm{kg}$ and $200 \mathrm{mg} /$ $\mathrm{kg}$ significantly $(p<0.05)$ reduced pain stimuli, whereas a treatment dose of $100 \mathrm{mg} / \mathrm{kg}$, $200 \mathrm{mg} / \mathrm{kg}$, and $400 \mathrm{mg} / \mathrm{kg}$ significantly $(p<0.05)$ reduced the edema volume increment. However, compared with the positive control, paracetamol and diclofenac were associated with the least pain stimulus and the least edema volume increment, respectively. Potato peel extract against Streptococcus mutans biofilm formation demonstrated effectiveness $(p<0.05)$. Based on these data, it can be concluded that potato peel extract has analgesic, anti-inflammatory, and anti-biofilm-forming activities, as demonstrated in this study.
\end{abstract}

Keywords: Potato peel extract, anti-inflammatory, analgesic, edema, pain, anti-biofilm

\section{INTRODUCTION}

Currently, considerable emphasis is placed on the development of new and safer medicines (Nayagam and Shobana, 2012). The utilization of natural resources, one of which one is plants, has been researched as an alternative to synthetic drugs because of their natural content. Since the medicinal benefits of only around $11 \%$ of the plants in Indonesia are known, there are many plants with as yet undiscovered therapeutic benefits (Solikin, 2007). One of them is potato (Solanum tuberosum L.).

Submitted: November 21, 2019

Revised: January 15, 2020

Accepted: January 20, 2020

*Corresponding author: ivanwahyudi_drg@ugm.ac.id 
In a previous study, potato peels, the part of potato that is often cut off and discarded, were reported to have some phenolic compounds and flavonoids in their composition (Schieber and Saldaña, 2009). Phenolic acids were observed in potato peel extracts (Samarin, et al., 2012). A flavonoid is a chemical compound with proven analgesic and anti-inflammatory effects (Mutalik, et al., 2003). Flavonoids may exert their beneficial effects via several mechanisms, one of which is inhibition of the activity of cyclooxygenase and lipoxygenase (Nayagam and Shobana, 2012). Therefore, potato peel extract (PPE) is proposed to have analgesic, anti-inflammatory, and anti-biofilm-forming activities because of its flavonoid content. Such activities were observed in this study by means of a hot plate test and carrageenan-induced paw edema in Wistar rats, as well as a crystal violet assay. As far as the authors are aware, there is no work carry out on.

\section{MATERIALS AND METHODS}

\section{Materials}

\section{Analgesic Activity}

This study involved 25 male Wistar rats, which were divided into 5 groups: a negative control group (distilled water $10 \mathrm{mg} / \mathrm{kg}$ ), PPE group $(50 \mathrm{mg} / \mathrm{kg}, 100 \mathrm{mg} / \mathrm{kg}$, and $200 \mathrm{mg} / \mathrm{kg}$ ) and positive control group (paracetamol $45 \mathrm{mg} / \mathrm{kg}$ ).

\section{Anti-inflammatory Activity}

This study involved 30 male Wistar rats, which were divided into 5 groups: a negative control group (distilled water $10 \mathrm{mg} / \mathrm{kg}$ ), PPE group (100 $\mathrm{mg} / \mathrm{kg}, 200 \mathrm{mg} / \mathrm{kg}$, and $400 \mathrm{mg} / \mathrm{kg}$ ) and positive control group (sodium diclofenac $6.5 \mathrm{mg} / \mathrm{kg}$ ).

\section{Anti-Biofilm Activity}

The bacteria chosen for anti-biofilm assay were Streptococcus mutans ATCC 25175.

\section{Methods \\ Analgesic activity}

Pain stimuli in rats were observed by placing them on a hotplate with a constant temperature of $60^{\circ} \mathrm{C}$ and observing the response of licking or jumping up on the hind legs. The treatments were administered orally $1 \mathrm{~h}$ before the test. The time interval between the stimulus and the response to pain was noted as the latency time (in seconds). The mean of the latency time was determined for each group.

\section{Anti-Inflammatory Activity}

Edema volume was observed by using a plethysmometer (Ugo Basile, Italy) $1 \mathrm{~h}$ before inducing inflammation by injecting $1 \%$ carrageenan into the left paw of rats and $1 \mathrm{~h}, 2 \mathrm{~h}, 3 \mathrm{~h}$ and $4 \mathrm{~h}$ after oral treatment administration. The percentage volume of edema was calculated by using the following formula:

$$
\text { \%Edema volume }=\left(\mathrm{V}_{\mathrm{T}}-\mathrm{V}_{0}\right) / \mathrm{V}_{0} \times 100 \%
$$

Paw volumes after $1 \mathrm{~h}, 2 \mathrm{~h}, 3 \mathrm{~h}$ and $4 \mathrm{~h}$ were referred to as $\left(\mathrm{V}_{\mathrm{T}} \cdot \mathrm{V}_{0)}\right.$ referred to the initial paw volume before treatment administration.

\section{Anti-Biofilm Activity}

The ability of bacteria to form biofilm was quantified by the crystal violet assay. The biofilms were washed gently with natrium perborat (PBS) without interfering with its attachment to remove free-floating bacteria. Biofilm formed were stained with $0.1 \%$ crystal violet and incubated at room temperature for 15 minutes. The excess stain was rinsed off with PBS ( $\mathrm{pH}$ 7.2) twice to ensure that there was no residual extract. The stained biofilms were taken from the wells by adding $50 \mu \mathrm{L}$ of ethanol and then transferred to the wells that were still empty for the purpose of fixation. Biofilms were measured by using an enzyme-linked 
immunosorbent assay (ELISA) reader microplate, which was set at a wavelength of $540 \mathrm{~nm}$. Biofilm formation was indicated by the optical density value (OD). The percentage of biofilm inhibition was calculated according to the formula:

\section{[(OD growth control-OD sample)/OD growth control $] \times 100$}

\section{Data Analysis}

All data represented from the average of triplicate analyses and recorded as mean $\pm \mathrm{SD}$. The data were subjected to analysis of variance (ANOVA) followed by a post hoc least significant difference (LSD) test. Correlation analysis was performed by using SPSS version 22 for windows.

\section{RESULTS}

\section{Analgesic Activity}

The PPE groups $(100 \mathrm{mg} / \mathrm{kg}$ and $200 \mathrm{mg} /$ $\mathrm{kg}$ ), which are described in Figure 1, showed a longer latency time, indicating a greater ability to reduce pain, compared with the negative control group. However, the longest latency time was shown by the positive control group. The differences in latency times among groups were statistically significant, which was shown by the one-way ANOVA test result score of 0.000 $(p<0.05)$. The results of the LSD test also showed that there was a significant difference between

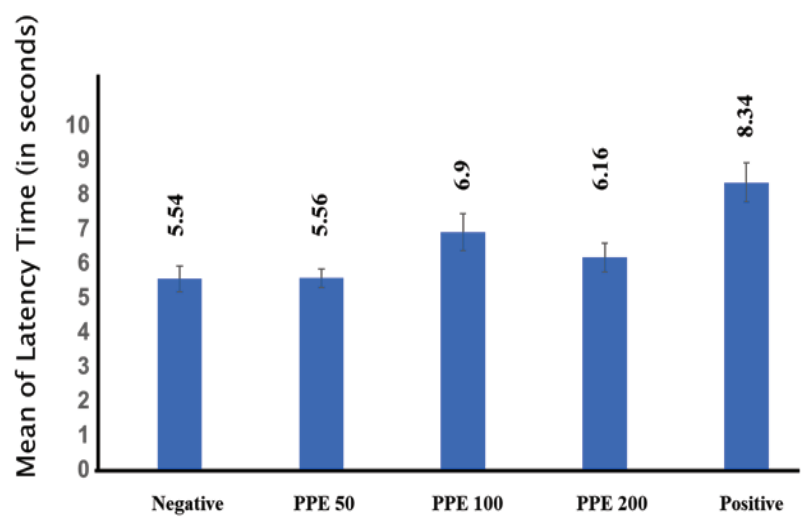

the mean latency time in the positive control group and all other treatment groups $(p<0.05)$.

\section{Anti-Inflammatory Activity}

The PPE groups $(100 \mathrm{mg} / \mathrm{kg}, 200 \mathrm{mg} / \mathrm{kg}$, and $400 \mathrm{mg} / \mathrm{kg}$ ), which are described in the Figure 2 , had a lower edema volume increment than the negative control group. However, the lowest edema volume increment was shown by the positive control group. According to one-way ANOVA, $1 \mathrm{~h}$, $2 \mathrm{~h}, 3 \mathrm{~h}$, and $4 \mathrm{~h}$ observations showed significance scores, respectively, all of which were lower than $0.05(p<0.05)$. It can be concluded that the edema volume increment among treatment groups was statistically significantly different. The result of the LSD test showed statistically significant differences in the edema volume increment between the following groups: the PPE group, positive control group, and negative control group from the second to the to the forth hour of observation $(p<0.05)$.

\section{Anti-Biofilm Activity}

The results of the anti-biofilm-formation activities of $S$. mutans in order from low to high were negative control, $5 \%, 10 \%, 20 \%$ and positive control respectively are presented in Figure 3 . There was a significant difference in the biofilm formation inhibitory activities of $S$. mutans between treatments (5\% PPE, $10 \%$ PPE, $20 \%$ PPE), the positive control, and the negative control groups (Table 1).

\author{
Negative : Negative Control (distilled water 10 \\ $\mathrm{mg} / \mathrm{kg}$ ) group \\ PPE 50: Potato Peel Extract $50 \mathrm{mg} / \mathrm{kg}$ group \\ PPE 100 : Potato Peel Extract $100 \mathrm{mg} / \mathrm{kg}$ group \\ PPE 200 : Potato Peel Extract $200 \mathrm{mg} / \mathrm{kg}$ group \\ Positive: Positive Control (paracetamol $45 \mathrm{mg} / \mathrm{kg}$ ) \\ group
}

Figure 1. Mean latency time in the pain response. 


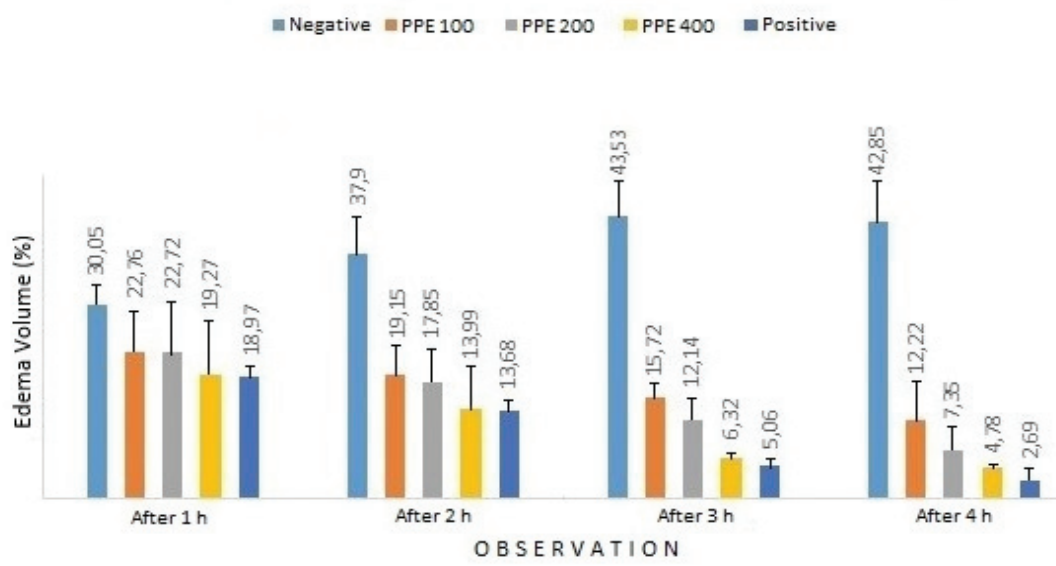

Negative: Negative Control (distilled water $10 \mathrm{mg} / \mathrm{kg}$ ) group

PPE 100: Potato Peel Extract $100 \mathrm{mg} / \mathrm{kg}$ group

PPE 200: Potato Peel Extract 200 mg/kg group

PPE 400: Potato Peel Extract 400 mg/kg group

Positive: Positive Control (sodium diclofenac $6.5 \mathrm{mg} / \mathrm{kg}$ ) group

Figure 2. Increment in edema volume at $4 \mathrm{~h}$ of observation.

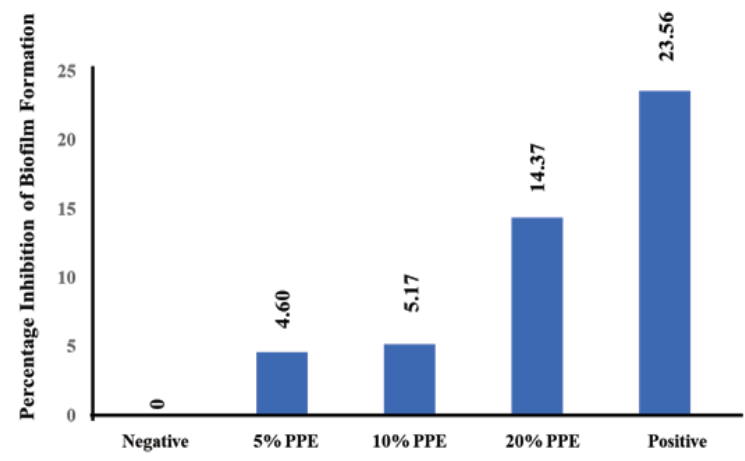

Figure 3. The anti-biofilm-formation activities of Streptococcus mutans.

\section{DISCUSSION}

The present study was undertaken to investigate the analgesic and anti-inflammatory activities of PPE extract in rats. Laboratory experiments were conducted using a hot plate test to assess analgesic activity and carrageenan-induced paw edema to assess anti-inflammatory activity. These models are commonly used in the field of analgesic and anti-inflammatory studies.

In the analgesic test, pain was described as the body's defense mechanism against damage that would trigger the individual to dodge react (reflex) and stop. Pain could be felt through a variety of

Table 1. Least significant difference test result (anti-biofilm)

\begin{tabular}{cccccc}
\hline Group & control (-) & $5 \%$ & $10 \%$ & $20 \%$ & control (+) \\
\hline control (-) & - & $0.004^{*}$ & $0.000^{*}$ & $0.004^{*}$ & $0.005^{*}$ \\
$5 \%$ & - & - & 0.913 & 0.303 & $0.027^{*}$ \\
$10 \%$ & - & - & - & 0.349 & $0.031^{*}$ \\
$20 \%$ & - & - & - & - & 0.109 \\
control (+) & - & - & - & - & - \\
\hline
\end{tabular}

note: ${ }^{*} p<0.05$ 
stimuli, such as temperature, chemical, or mechanical stimuli (Hall and Guyton, 2012). This study used temperature to stimulate the nociceptor pain centers, which produce pain mediators through the cyclooxygenase (COX) and lipoxygenase (LOX) pathways. Inhibiting those pathways will lead to a reduction in pain (Wilmana and Gan, 2007; Hall and Gan, 2012).

In the anti-inflammatory test, the development of edema in the rat paw following the injection of carrageenan has been described as biphasic, including an early phase and a late phase (Gupta, et al., 2006; Necas and Bartosikova, 2013). In the early phase, inflammation occurred due to trauma caused by carrageenan. This phase, which releases histamines and serotonins, could have occurred within 1 to $2 \mathrm{~h}$ after injection of carrageenan. The next phase, the late phase, was connected with the release of prostaglandin continuously, mediated by bradykinins, leutrokienes and PMN cells (Gupta, et al., 2006). Based on the theory and compared to this study, PPE might inhibit the edema volume increment from the early phase. It may be associated with the natural content of potato peel, flavonoid, which can inhibit the release of histamines and serotonins in the first $2 \mathrm{~h}$ of observation (Kim, et al., 2004; Sandhar, et al., 2011). The anti-inflammatory effect also might be linked to the role of flavonoids as an anti-oxidant agent, which could eliminate free radicals (Kim, et al., 2004). Free radicals are believed to be mediators in the process of inflammation (Ali, et al., 2012).

The results from the analgesic and anti-inflammatory tests might be associated with the presence of the potential natural pain-reducing contents, one of which is flavonoid. By blocking the activity of COX and LOX, flavonoids could impede the synthesis of prostaglandins and leukotrienes, the mediators of the pain and inflammation (Sandhar, et al., 2011).

PPEs have some phenolic compounds, chlorogenic acid and gallic acid. Chlorogenic acid has antibacterial properties by increasing the permeability of the outer membrane and plasma membrane, resulting in cytoplasmic leakage including nucleotides, and involved in the synthesis of fatty acids with the inhibition of certain enzymes associated with these fatty acids. Gallic acid is a derivative of benzoic acid with three hydroxyl groups. Gallic acid has antibacterial, antiviral, antifungal, antitumor, and anti-inflammatory properties. Phenolic compounds are also believed to disrupt the production of exopolysaccharide layer (EPS), which has the function of maintaining the integrity of the biofilm; therefore phenolic compounds are believed to inhibit biofilm formation (Hoffmann, 1951; Chaieb, et al., 2011).

\section{CONCLUSION}

This study demonstrated the analgesic and anti-inflammatory activities of PPE and showed that potato peel extract could be of importance in drug development, especially in the field of pain, inflammation relief, and anti-biofilm formation. Further studies on the toxicity and nature of the active components are required to determine additional clinical applications.

\section{ACKNOWLEDGMENT}

Part of this work has been funded through Dana Masyarakat research scheme.

\section{REFERENCES}

Ali. M.N.I., Annegowda, H.V., Mansor, S.M., Ismail, S., Ramanathan, S. and Mordi, M.N., 2012, Phytochemical screening, Antioxidant and Analgesic activities of Croton argyratus ethanolic extracts, Journal of Medicinal Plants Research, 6(21), 3724-3731.

Chaieb, K., Koudhi, B., Jrah, H., Mahdouani, K. and Bakhrouf, A., 2011, Antibacterial activity of Thymoquinone, an active principle of Nigella sativa and its potency to prevent bacterial biofilm formation, BMC Complementary and Alternative Medicine, 11(29). 
Gupta, M., Mazumder, UK., Gomathi, P. and Selvan, V.T., 2006, Antiinflammatory evaluation of leaves of Plumeria acuminata, BMC Complementary and Alternative Medicine, 6(36).

Hall, J.E. and Guyton, A.C., 2012, Guyton dan Hall Buku Ajar Fisiologi Kedokteran, $11^{\text {th }}$ Ed, Jakarta: EGC.

Hoffmann, D., 1951, Medical herbalism: The science and practice of herbal medicine, Rochester, Vermont: Healing Arts Press, 2003.

Kim, H.P., Son, K.H., Chang, H.W. and Kang, S.S., 2004, Anti-inflammatory plant flavonoids and cellular action mechanisms, Journal of pharmacological sciences, 96(3), 229-245.

Mutalik, S., Paridhavi, K., Mallikarjuna, R.C. and Udupa, N., 2003, Antipyretic and analgesic effect of leaves of Solanum melongena Linn. in Rodents, Indian Journal of Pharmacology, 35(5), 312-315.

Nayagam, A.A.J. and Shobana, G., 2012, Anti-inflammatory activity of Talinum fruticosum $L$. on formalin induced paw edema in albino rats, Journal of Applied Pharmaceutical Science, 02(01), 123-127.
Necas, J. and Bartosikova, L., 2013, Carrageenan: a review, Veterinární Medicína. Prague: Czech Academy of Agricultural Sciences, 58(4), 187205.

Samarin, A.M., Poorazarang, H., Hematyar, N. and Elhamirad, A., 2012, Phenolics in potato peels: Extraction and utilization as natural antioxidants, World Applied Sciences Journal, 18(2), 191-195.

Sandhar, H.K., Kumar, B., Prasher, S., Tiwari, P., Salhan, M. and Sharma, P., 2011, A Review of Phytochemistry and Pharmacology of Flavonoids, Internationale Pharmaceutica Sciencia, 1(1), 25-41.

Schieber, A. and Saldaña, M., 2009, Potato Peels: A Source of Nutritionally and Pharmacologically Interesting Compounds -A Review, Food, 3(Special Issue 2), 23-29.

Solikin, 2007, Potensi Jenis-jenis Herba Liar di Kebun Raya Purwodadi sebagai Obat, Purwodadi: LIPI.

Wilmana, P.F. and Gan, S., 2007, Farmokologi dan Terapi, $5^{\text {th }}$ Ed, Jakarta: Fakultas Kedokteran Universitas Indonesia. 